\title{
A Content Analysis of Online Brand Personality of 4 Universities in Ghana
}

\author{
Rhodalene Amartey ${ }^{1 *} \quad$ Nathan Austin ${ }^{2}$ \\ 1.Ghana Institute of Journalism. P. O. Box 667, Accra \\ 2.University of Professional Studies, Accra. P. O. Box L49, Legon
}

\begin{abstract}
The purpose of the study is to understand brand personality of four (4) universities in Ghana as communicated via their websites. Data was extracted from the websites of the 4 universities unto a word document. The text was analyzed using a content analysis technique. The Nvivo software version 12 was used to code the data. The results showed that the four (4) universities exhibit certain brand personality traits on their websites. For example, Kwame Nkrumah University of Science and Technology School of Business (KNUST Business School) and the University of Ghana Business School (UGBS) portrayed the following brand personality traits; competence, excitement, ruggedness, sincerity and sophistication. The University of Cape Coast School of Business (UCC School of Business) and the University of Education Winneba Faculty of Business (UEW Faculty of Business) exhibited the following brand personality traits; competence, ruggedness, sincerity and sophistication. The study concludes that the universities understand brand personality and strategically communicate them on their websites.
\end{abstract}

Keywords: brand personality, branding, Universities in Ghana, content analysis

DOI: $10.7176 / \mathrm{JEP} / 10-3-02$

\subsection{Introduction}

There are about 65 accredited universities with functional websites in Ghana. All these universities have consistently been attracting adequate students year after year for their survival. While some are struggling to grow their student populations, others have seen increase in student population.

Competition among universities in Ghana have intensified especially in the area of graduate programmes. Apart from the competition among these local universities, the universities also face fierce competition from foreign universities. In order to survive the competition, many of these universities have resorted to marketing and communication strategies. For example, branding is now a critical part of the marketing strategy for many of them, especially among the leading universities such as University of Ghana, and Kwame Nkrumah University of Science and Technology. These universities have created brand personality and brand identity in order to appeal to students.

Building a solid brand identity and communicating same, helps these universities to promote and communicate a coherent and consistent message to its stakeholders; distinguish its offering from that of the competition in order to charge a premium price and sustain student growth (Opoku, Abratt and Pitt, 2006).

People buy products and services that enable them to achieve maximum utility by way of the product's instrumental meaning, and also communicate their personalities or increase their self-esteem via the symbolic meaning of the brand they buy (Slaughter et al., 2004). Consumers usually have the tendency to associate themselves with certain brands that are consistent with their personality. Thus, they normally buy these brands and become loyal to them.

Research has shown that the success of organizations' success largely depends on their ability to build and communicate brand identities that are consistent with that of their consumers. Aaker and Joachimsthaler (2000) opine that brands without a personality face the challenge to build and maintain relationships with customers and other stakeholders.

Brand personality has received a considerable attention. Aaker (1997) defined brand personality as "the set of human characteristics associated with a brand" (p.347). Following this definition, Opoku et al. (2006) argued that "brand personality traits entails the core values of the organization and these traits should show up on all available communication media such as brochures, newsletters, community outreach materials, testimonials and, web sites. The effectiveness of a website in brand personality communication has been studied, however, limited studies have been done in the areas of higher education institutions (Opoku et al. 2006).

The purpose of this study is understand the brand personality of four (4) universities in Ghana as communicated via their websites. These universities are University of Ghana, Kwame University of Science and Technology, Cape Coast, and University of Education, Winneba.

The rest of the paper is divided as follows; context of the study, literature review, conceptual framework, methodology, presentation of findings, discussion and conclusions. 


\subsection{Literature Review}

Studies on brand personality in higher education: Anthropomorphized university marketing communications" by Rutter et al (2016) established that in times past, most universities used prospectus as the marketing communication and recruitment strategic tool. However, in recent times the focus has shifted to other channels such as social media and websites. In this study the researchers explored and analyzed prospectus of 10 top higher educational institutions in UK. They used brand personality to compare their relative positions. The findings indicated that sincerity a personality trait was common to all the institutions whilst the other traits had clear differentiation. Excitement and competence ranked high among the 10 institutions. The study recommends that other researchers should look at brand personality as perceived by students and not by the university. Besides, the scope of the study should be broadened so that the findings can be generalized. This clearly shows that this study has limitations. Therefore, this study will focus on the brand personality of websites of universities.

Studies of how human personality affects various aspects of consumer behavior have been widely conducted, but studies of brand personality began only recently, although in the field of marketing several studies have already been completed and published. For example, Plummer (1985) studied how brand personality affects consumers' choice of a soft drink with a distinctive brand image in the United States. Aaker (1996) summarized the role of brand personality in building up brand power and pointed out the importance of and the need for empirical research. Aaker (1997), after realizing the need for further empirical research, developed a new measurement scale for measuring brand personality along five dimensions, extracted from her research. These five dimensions were sincerity, excitement, competence, sophistication, and ruggedness. But these studies have not shown how brand personality affects important marketing variables such as brand loyalty or online brand elements.

With brands emerging as the top management's priority (Ailawadi \& Keller, 2004), marketing research has focused on the symbolic meaning consumers attribute to brands (Austin et al., 2003). One such symbolic meaning is brand personality (Aaker, 1997; Zentes et al, 2008; and Geuens et al., 2009). Marketers believed that the harder aspects of brands like the functional attributes have more impact on consumer purchase behavior than its softer aspects like personality (Biel, 1993). However, some studies believed that brand personality plays an important role in differentiating similar products, as it is less weighed by physical attributes (Biel, 1993; Halliday, 1996).

Research has established that while a brand's physical attributes like features, price and materials may change sometimes or frequently, brand personality is an enduring quality, resisting change (Biel, 1993). Brand personality serves as a sustainable competitive advantage for the firm (Aaker, 1996) and it has great influence on brand equity (Batra et al., 1993; Biel, 1993; Keller, 1993; and Aaker, 1996). While, Biel (1993) viewed personality as a driver of consumer buying behavior, Plummer (1984) found that it could be used to market a brand across culture. Fournier (1994) and Aaker (1996) found that consumer segmentation and brand strategy of a firm are formed based on brand personality-customer relationship. This helps the firm to attract customers through various marketing mix elements (Fournier, 1994; and Aaker, 1996). Biel (1993) and Aaker (1997) suggested that customers derive more personal meaning from their interpretation of the brand's association. Aaker (1997) argued that consumers find self-expression through the brand personality. Consumers partly express their social self through using products whose cultural meanings are close to what they are or want to become (McCracken, 1989). To achieve this, the brand's personality should be strong enough to matter to the consumers (Aaker, 1996). Researchers found out that the relationship between brands and customers could be strengthened through brand personality (Blackston, 1993; and Aaker, 1996) by creating 'feeling' or 'liking' towards the brands (Aaker, 1996). Finally, studies found that brand personality positively influences purchase decision of a product (Biel, 1993; Blackston, 1993; and Aaker, 1996).

Despite these obvious reasons, the research on brand personality is somehow limited. Due to lack of consensus regarding what brand personality is, the symbolic use of brands has also remained limited (Aaker, 1997). How is it defined? Does it have a framework or a set of dimensions similar or different from the 'Big Five' dimensions of human personality? (Aaker, 1997). These questions remind us that rigorous attention to the concept of brand personality is needed. This would involve a comprehensive review of brand personality studies pertaining to scale development.

Distinct brand personality plays a key role in the success of a brand. It leads customers to perceive the brand personality and develop a strong connection to the brand (Doyle, 1990). A brand personality should be shaped to be long-lasting and consistent. Besides, it should also be different from other brands and meet consumer's demands (Kumar et al., 2006). Hence, the consumers of those toys and video games are like the brand spokespersons and become the basis for suppliers to build brand personality. With the specific brand personality, consumers of varying personality traits will be attracted, and their brand preference will then be further developed. In addition, a company can maintain a good relationship with customers through its brand personality (Aaker and Biel, 1993). 
Since brands have their own personalities, consumers may treat brands as real human beings. In this case, consumers will expect the people's words, attitudes, behavior or thoughts and so on to meet their respective personality traits (Aaker, 1996). Consumers may likely use the brand and products in line with their own personality traits, in other words, all the marketing activities are aimed at having consumers believe and recognize a brand personality and reinforcing the communication between the brand and the consumer (Govers \& Schoormans, 2005), in order to enhance the brand's loyalty and equity.

Brand personality has become a widely discussed issue in recent years. It has been emphasized in many brands and products, including durables goods, consumables goods, entertainment and luxury goods, and so on (Kumar et al., 2006; Govers and Schoormans, 2005; Mengxia, 2007). Consumers may have their own preference for the brand and product in compliance with their brand personality and personality traits or their own concepts (Govers and Schoormans, 2005). However, in fact, brand preference only involves in the affection in brand loyalty, it may not develop any purchase behavior (Dyson et al., 1996). The literature reviewed indicate that much has been done with regards to brand personality offline but not online. This study aims at investigating the communication of brand personality on universities websites by using te qualitative content analysis method.

\subsection{Brand Personality Framework}

According to the psychology literature, the concept 'personality' has two completely different meanings. Firstly, personality concerns an individual's internal processes and propensities. This meaning has been used to explain why people act in a particular way. The second perspective looks at personality from an individual's social reputation. That is the way an individual is perceived by others, such as family, friends, co-workers and the community (Hogan, 1991). In this view, personality is public and outward and confirmable; it is concerned with the amount of esteem, regard, and status accorded a person by outsiders. Putting them together, it can be said that personality comprises both the internal and external traits of an individual. It can also be said that personality is both a conception and a perception. Over the years, marketers have tried to use human features to describe brands. Brand personality is an example of instances where human attributes have been transferred to brands. It is assumed that brands like human beings have certain inherent traits and these traits can be perceived. In this research, the focus was on the brand personality of universities in Ghana which can be perceived via their websites.

Aaker (1997) conceptualized brand personality from five dimensional perspectives; sincerity, excitement, competence, sophistication and ruggedness. Sincerity has attributes such as; down to earth, cheerful, wholesome, honest while excitement is defined via spirited, imaginative, daring, and up-to-date. Competence has features such as reliable, intelligence, and successful. Aaker (1997) identified upper class, and charming as the attributes of sophistication while ruggedness is defined using attributes such as outdoorsy and tough.

Following the five dimensions, Opoku (2005) identified additional attributes for each of the dimensions in his study of brand personality of Business Schools in South Africa. These attributes are captured in figure 1.

\begin{tabular}{|l|l|l|l|l|}
\hline Competence & Excitement & Ruggedness & Sincerity & Sophistication \\
\hline smart & active & external & straight & clegant \\
\hline thorough & colourful & rigorous & original & excellent \\
\hline guarantec & cool & robust & open & attractive \\
\hline enterprise & current & difficult & helpful & exclusive \\
\hline industrious & exciting & stony & real & royal \\
\hline successful & exhilarating & tough & standard & charm \\
\hline comprehensive & modem & enduring & practical & clegant \\
\hline venture & present & endeavours & authentic & stylish \\
\hline able & recent & trek & relationship & beautiful \\
\hline leader & state-of-the art & wild & humane & distinction \\
\hline adept & unique & challenges & friendly & cosmopolitan \\
\hline knowledgeable & vibrant & physical & positive & high-profile \\
\hline intellectual & younger & grueling & civil & exquisite \\
\hline
\end{tabular}

\section{Source: Opoku (2005)}

Since this study seeks to understand brand personality of universities in Ghana, Opoku's framework was adopted. Content analysis method was also employed to explore the brand personality of the universities.

\subsection{Content Analysis}

Weber (1990) defines a content analysis as a systematic replicable technique for compressing many words of text into fewer content categories based on the explicit rules of coding. Bevelson (cited in Kaid \& Wadsworth, 
1989) threw light on one of the most widely acknowledged definitions of content analysis as a research technique for the objective, systematic and quantitative description of the manifest content of communication". Content analysis allows the researcher to delve into large amounts of data in a systematic fashion and in an easy manner (Stemler 2001). It involves codifying a text (or content) of a piece of writing into various classes depending on a selected criteria (Weber, 1988). It also involves a systematic identification of specific features of a text and classifying them based on a selected (Stone et al., 1966). Neuman (2003) identifies words, meanings, pictures, symbols, ideas, or any textual format that can be communicated as contents that be analyzed. Opoku et al. (2007) assert that content analysis is both a technique for gathering and analyzing. Content analysis is both a quantitative and qualitative technique (Neuman, 2003). In this study, the qualitative technique of the content analysis method was employed based on Krippendorf (2004:19) argument: 'all reading of texts is qualitative, even when certain characteristics of a text are later converted into numbers'. The focus is to determine the presence of the attributes of the brand personality traits as shown in figure 1. This study is therefore based on the brand personality that the four (4) universities communicate on their websites.

\subsection{Methodology}

This study is part of a $\mathrm{PhD}$ thesis which studied the brand personality of 65 accredited universities with functional websites in Ghana. This study however focused on four (4) universities whilst the analysis was based on the contents of the webpage of the business schools/faculty of these universities. The universities and their Uniform Resource Locator (URL) are captured in table 1 (see Appendix A). The initial plan was to analyse the contents of the 65 websites. However, to conduct a detailed analysis, the study was limited to the business schools/faculties of these four (4) universities. This is because business schools are competition orientated and more likely to utilize marketing strategies in their communications than other faculties or even the whole university.

The unit of analysis include homepage of the university (about us, vision, mission) and the textual information available on the homepage of each of the universities' business school/ faculty. All the textual information from the homepage were extracted unto a word document. This researcher clicked all links and roots on the main portal and copied all information available into the same text document. This procedure was repeated for all the universities.

Opoku's (2005) instruments which were developed based on Aaker's (1997)' five brand personality dimensions were employed for the study. The items are captured in figure 1. In coding the text, Microsoft Word Thesaurus was used to identify, tag synonyms and identify the attributes of the five brand personality dimensions. The same approach was used to remove the synonyms that are inappropriate in this analysis. For example, advancement, initiatives, innovation, innovative, institutes, institution, institutions were tagged under Sophistication, however, foundation/ foundations.

The qualitative technique of content analysis was used to analyse the data. Neuman's (2003) list of words, meanings, pictures, symbols, ideas, themes were used as contents that could be analyzed. Text was analyzed since it contained the attributes being identified. This method is widely used in social science research. Content analysis is commonly regarded as a useful method for media and communication research (Kolbe and Burnett, 1991). The Nvivo software version 12 was used to code the data. Following, Boateng, Okoe, and Hinson (2018), Boateng and Narayan (2017) and Boateng and Abdul-Hamid (2017), extracts from the texts were used to support the researcher's arguments to ensure the trustworthiness of the results.

\subsection{Presentation of Findings}

The content analysis revealed that the four (4) universities communicate various brand personality traits on their websites. UGBS and KNUST Business School communicated competence, ruggedness, sophistication, sincerity and excitement on their websites while UEW Faculty of Business and UCC School of Business portrayed competence, ruggedness, sophistication and sincerity on their websites.

Further analysis revealed that UGBS portrayed "competence" as their dominant brand personality. As shown in figure 2, they had 21 coding reference. However, this number was less than the corresponding coding reference for KNUST Business School which had 40 coding reference for the "competence" brand personality dimension (see figure 3). 


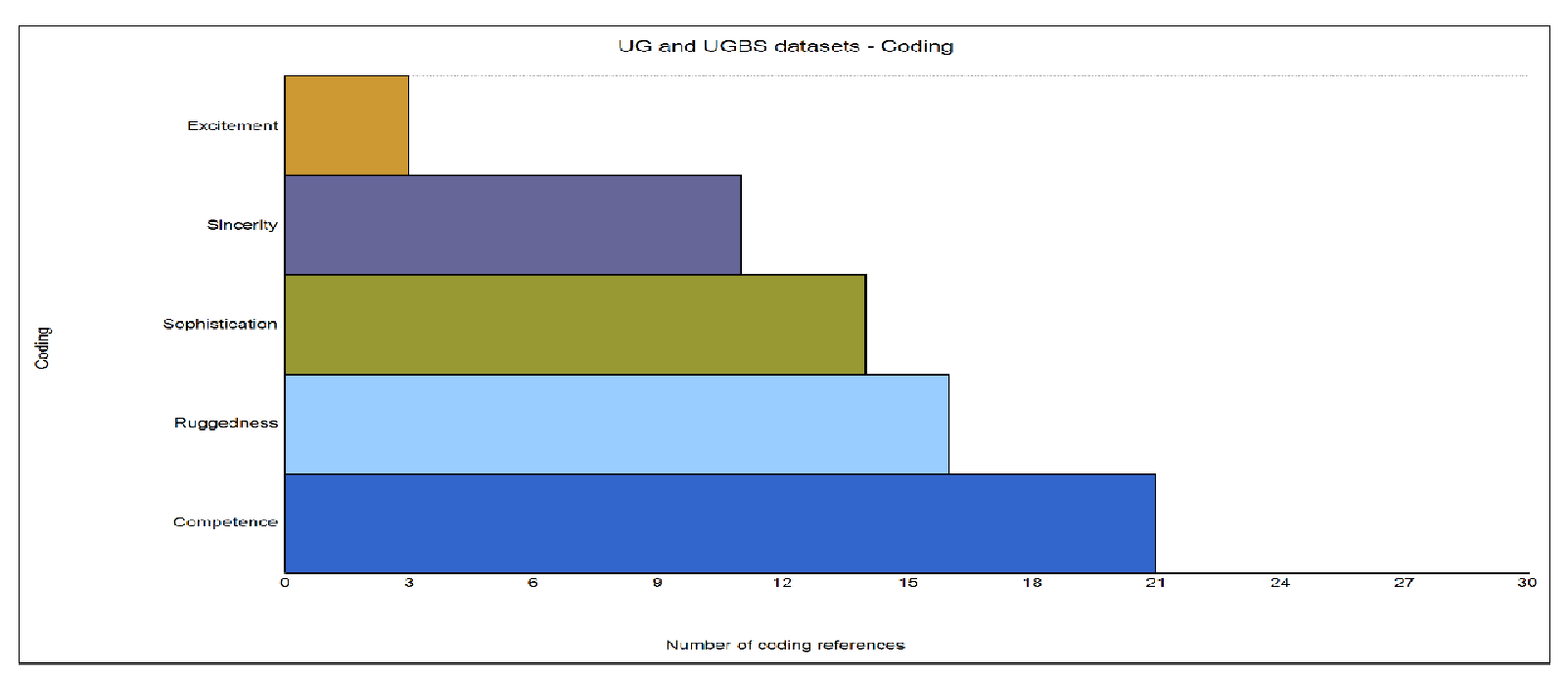

Figure 2: Coding reference: UGBS

The results showed that among the 4 universities, KNUST Business School had the strongest competent personality online. Competent attributes such as professional, employment, experienced, and industrial are some of the words that UGBS used to portray their competence personality on their website (see table 1).

Additionally, UGBS depicted ruggedness personality. This dimension ranked second in terms of the coding reference (see figure 2). The university used attributes such as sustainability, aggressive and overcoming challenges to display their ruggedness personality. Table 1 (below) provides details of the words frequently used by UGBS to portray their personality on their website. The table also shows the weighted percentage and synonyms of words used to describe each of the components of universities' brand personalities.

\begin{tabular}{|c|c|c|c|c|}
\hline $\begin{array}{l}\text { Personality } \\
\text { dimensions }\end{array}$ & Attributes & Frequency & $\begin{array}{l}\text { Weighted } \\
\text { Percentage (\%) }\end{array}$ & Similar Words \\
\hline \multirow[t]{12}{*}{ Competence } & entrepreneurship & 11 & 0.15 & Entrepreneurship \\
\hline & enterprises & 12 & 0.12 & enterprise, enterprises, entrepreneurs \\
\hline & certification & 6 & 0.08 & Certification \\
\hline & specialist & 5 & 0.05 & specialises, specialist \\
\hline & accreditation & 7 & 0.05 & accreditation, recognized \\
\hline & entrepreneurial & 16 & 0.21 & Entrepreneurial \\
\hline & capabilities & 15 & 0.20 & capabilities, competence, competencies \\
\hline & employment & 27 & 0.33 & employability, employable, \\
\hline & industrial & 24 & 0.32 & industrial, industries \\
\hline & experienced & 26 & 0.35 & experience, experienced, experiences \\
\hline & professional & 30 & 0.40 & professional, professionals \\
\hline & leadership & 15 & 0.20 & Leadership \\
\hline \multirow[t]{4}{*}{ Excitement } & inspiration & 5 & 0.07 & aspirations, inspiration \\
\hline & enthusiasm & 3 & 0.04 & Enthusiasm \\
\hline & innovative & 76 & 0.76 & advancement, innovation, innovative, \\
\hline & technology & 27 & 0.33 & engineering, technology \\
\hline \multirow[t]{3}{*}{ Ruggedness } & sustainable & 10 & 0.13 & Sustainable \\
\hline & aggressive & 4 & 0.05 & Aggressive \\
\hline & challenges & 19 & 0.25 & challenges, challenging, competitive \\
\hline \multirow[t]{9}{*}{ Sincerity } & collegiate & 9 & 0.12 & collegiality, collegiate \\
\hline & partnerships & 8 & 0.11 & Partnerships \\
\hline & interactivity & 7 & 0.09 & interaction, interactivity, synergistic \\
\hline & relationships & 6 & 0.08 & relationship, relationships \\
\hline & satisfaction & 4 & 0.05 & Satisfaction \\
\hline & consulting & 14 & 0.19 & conferences, consultancy, consulting \\
\hline & engagement & 24 & 0.16 & involvement, , participate \\
\hline & association & 19 & 0.25 & affiliations, associated, connection \\
\hline & collaboration & 26 & 0.35 & collaborative, cooperation \\
\hline
\end{tabular}




\begin{tabular}{|l|l|l|l|l|}
\hline $\begin{array}{l}\text { Personality } \\
\text { dimensions }\end{array}$ & Attributes & Frequency & $\begin{array}{l}\text { Weighted } \\
\text { Percentage (\%) }\end{array}$ & Similar Words \\
\hline Sophistication & reputation & 7 & 0.09 & Reputation \\
\cline { 2 - 5 } & outstanding & 5 & 0.07 & Outstanding \\
\cline { 2 - 5 } & successful & 5 & 0.06 & achievements, successful \\
\cline { 2 - 5 } & principled & 4 & 0.05 & Principled \\
\cline { 2 - 5 } & international & 43 & 0.57 & \\
\cline { 2 - 5 } & excellence & 20 & 0.27 & Excellence \\
\cline { 2 - 5 } & opportunity & 26 & 0.35 & opportunities, opportunity \\
\hline
\end{tabular}

Table 1: UGBS' personality attributes

The KNUST Business School used words such as development, establishment, leadership, skills, competencies, industrial, entrepreneur and employment to showcase their "competence" personality on their website. For examples, words such as development appeared 61 times, establishment appeared 46 times, employment appeared 22 times and even the word competencies appeared 4 times (see table 2). Table 2 displayed all the personality dimensions, the descriptors of each personality component and word or descriptor frequency.

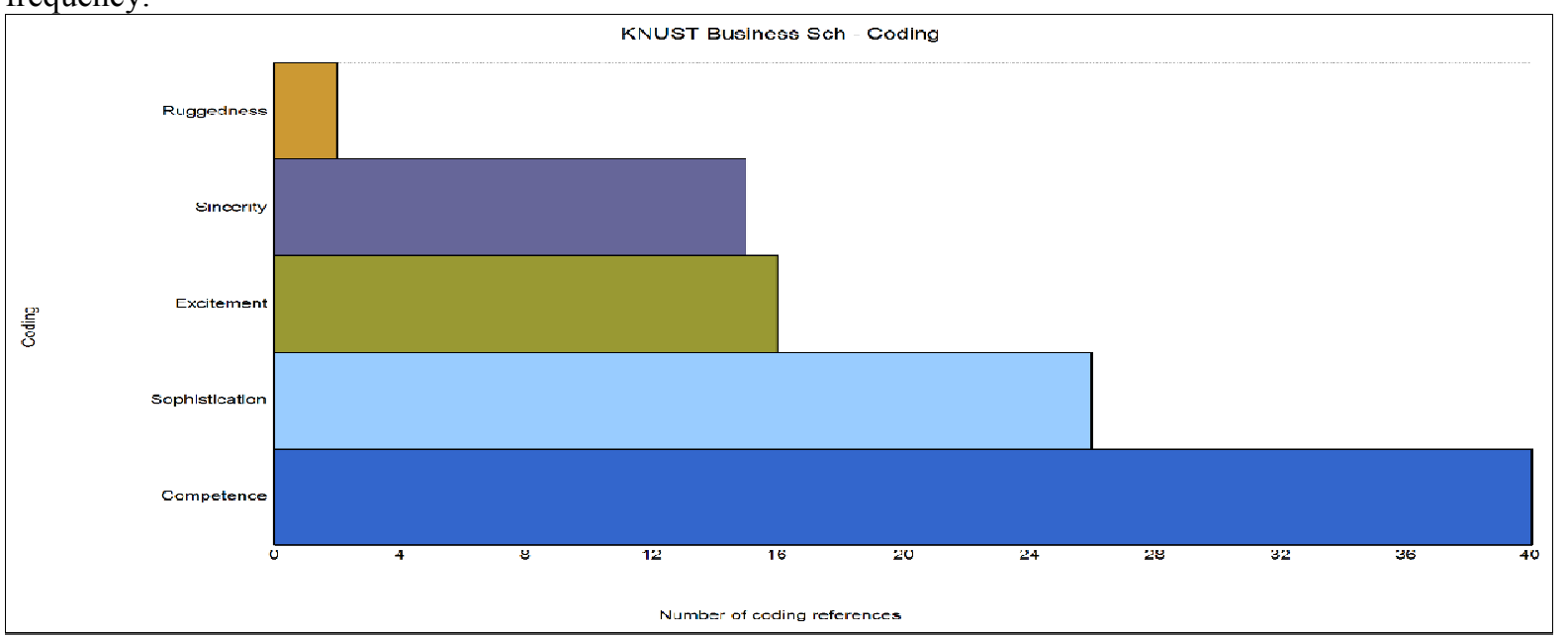

Figure 3: Coding reference: KNUST

KNUST Business School also portray themselves as a "sophisticated" personality. Sophistication had 25 coding references. This is higher than that of the UGBS (14 times). This suggests that KNUST Business School wants to be perceived by prospective students and stakeholders as "competent" to meet students' teaching and research needs as well as prepare them for the job market. For example, it is stated on the website that "employers in Ghana have taken notice of improvements at KSB and in a recent survey it was identified that the employment rate for graduates from KSB's undergraduate programme is over 90\%”.(www.knust.edu.gh/)

\begin{tabular}{|l|l|l|l|l|}
\hline $\begin{array}{l}\text { Personality } \\
\text { dimensions }\end{array}$ & Attributes & Frequency & $\begin{array}{l}\text { Weighted } \\
\text { Percentage (\%) }\end{array}$ & Similar Words \\
\hline Competence & development & 61 & 2.51 & \\
\cline { 2 - 5 } & establishment & 46 & 2.07 & establish, establishing, \\
\cline { 2 - 5 } & Leaders & 23 & 1.27 & leader, leaders, leadership \\
\cline { 2 - 5 } & Industrial & 19 & 1.20 & industrial, industries, industry \\
\cline { 2 - 5 } & competencies & 4 & 0.25 & competencies, competent \\
\cline { 2 - 5 } & Skills & 10 & 0.22 & expert, practical, practice, practices \\
\cline { 2 - 5 } & Leadership & 9 & 0.25 & leadership, leading, leads \\
\cline { 2 - 5 } & Training & 14 & 0.35 & coaching, directly, discipline, training \\
\cline { 2 - 5 } & employment & 22 & 1.03 & $\begin{array}{l}\text { employability, employable, employing, } \\
\text { employment, working }\end{array}$ \\
\cline { 2 - 5 } & experience & 11 & 0.66 & experience, experienced, experiences, \\
\cline { 2 - 5 } & professional & 9 & 0.57 & master, professional \\
\cline { 2 - 5 } & entrepreneurial & 8 & 0.51 & entrepreneurial \\
\cline { 2 - 5 } & economic & 7 & 0.44 & economic, economics \\
\cline { 2 - 5 } & research & 18 & 1.14 & Research \\
\hline
\end{tabular}




\begin{tabular}{|c|c|c|c|c|}
\hline $\begin{array}{l}\text { Personality } \\
\text { dimensions }\end{array}$ & Attributes & Frequency & $\begin{array}{l}\text { Weighted } \\
\text { Percentage (\%) }\end{array}$ & Similar Words \\
\hline \multirow[t]{2}{*}{ Excitement } & innovative & 28 & 1.12 & advance, advancing, concepts, \\
\hline & technology & 10 & 0.57 & engineering, technology \\
\hline \multirow[t]{3}{*}{ Ruggedness } & sustainable & 10 & 0.35 & nurturing, sustainable \\
\hline & Strong & 6 & 0.30 & secure, strong, warmly \\
\hline & committed & 9 & 0.23 & committed, dedicate, invest, investing, \\
\hline \multirow[t]{4}{*}{ Sincerity } & diversity & 5 & 0.22 & diversity, variety, various \\
\hline & Engage & 12 & 0.36 & engage, engaging, involvement \\
\hline & community & 13 & 0.61 & communication, communities \\
\hline & collaboration & 7 & 0.44 & collaborated, collaboration, partners \\
\hline \multirow[t]{7}{*}{ Sophistication } & Value & 7 & 0.37 & esteemed, rates, value, values \\
\hline & Success & 9 & 0.41 & $\begin{array}{l}\text { achieve, achievements, succeed, success, } \\
\text { successful }\end{array}$ \\
\hline & Systems & 10 & 0.41 & order, organizations, systems \\
\hline & opportunities & 6 & 0.38 & opportunities, opportunity \\
\hline & Value & 7 & 0.37 & esteemed, rates, value, values \\
\hline & excellence & 9 & 0.57 & excellence, excellent \\
\hline & international & 13 & 0.61 & International, outside \\
\hline
\end{tabular}

Figure 2: KNUST's personality attributes

In the case of UEW Faculty of Business, competence and ruggedness were the dominant brand personality traits available on their website. As shown in figure 4, these traits had 3 coding references each. The university, however, does not portray an excitement personality on the website. This is also the case of the UCC School of Business.

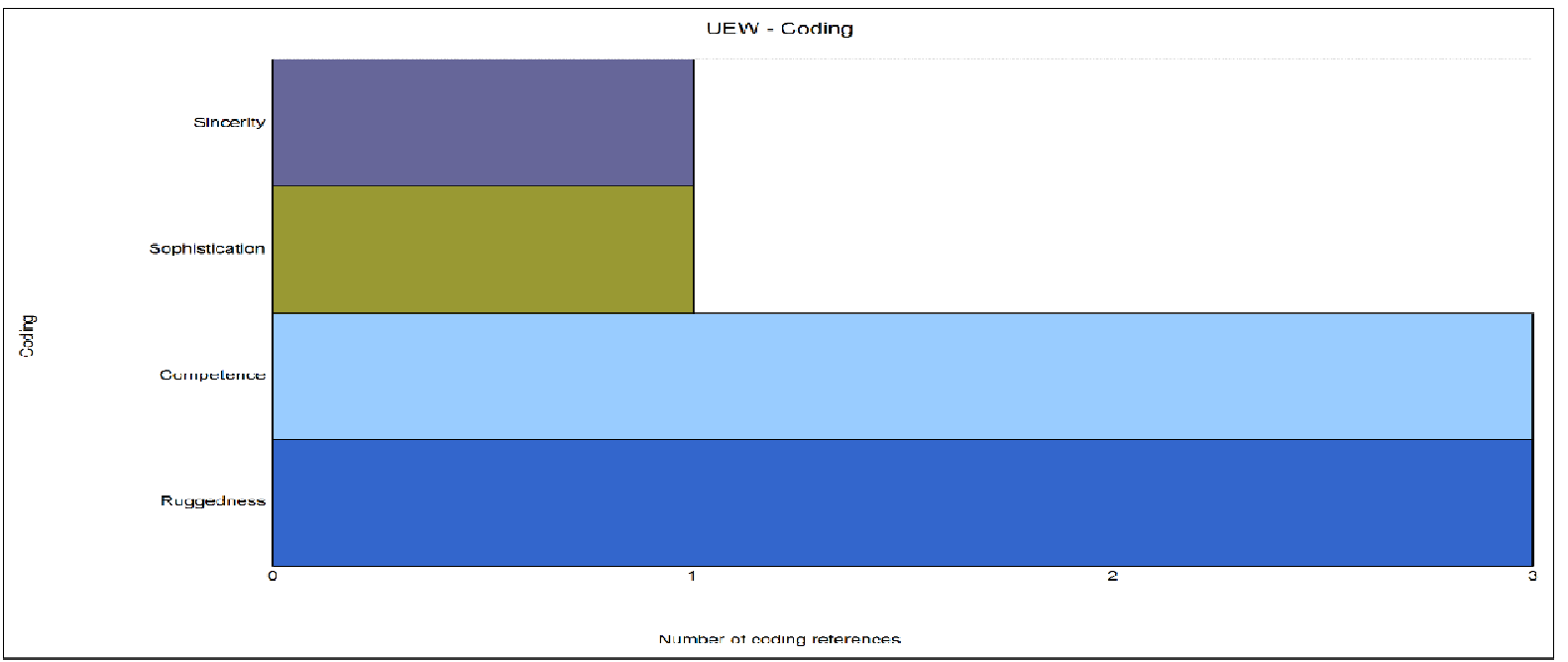

Figure 4: Coding reference: UEW

From table 3, it is obvious that UEW Faculty of Business' communicated "competence", professionalism and technical expertise. They also indicated how as a young institution they have survived many challenges to get to their current status. 


\begin{tabular}{|l|l|l|l|l|}
\hline $\begin{array}{l}\text { Personality } \\
\text { dimensions }\end{array}$ & Attributes & Frequency & $\begin{array}{l}\text { Weighted Percentage } \\
(\mathbf{\%})\end{array}$ & Similar Words \\
\hline \multirow{4}{*}{ Competence } & Faculty & 3 & 1.11 & faculties, faculty \\
\cline { 2 - 5 } & technical & 3 & 1.11 & technical, technology \\
\cline { 2 - 5 } & competence & 1 & 0.37 & Competence \\
\cline { 2 - 5 } & professional & 1 & 0.37 & Professional \\
\hline Ruggedness & Holistic & 1 & 0.37 & Holistic \\
\hline Sincerity & Links & 1 & 0.37 & Links \\
\hline Sophistication & World & 24 & 1.33 & $\begin{array}{l}\text { advabal, globally } \\
\text { upgrade }\end{array}$ \\
\cline { 2 - 5 } & advanced & 7 & 2.58 & advancement, \\
\cline { 2 - 5 } & Special & 4 & 1.48 & Status \\
\cline { 2 - 5 } & Status & 4 & 1.48 & \\
\hline
\end{tabular}

Table 3: UEW's personality attributes

Like the UGBS, KNUST Business School and UEW Faculty of Business, UCC School of Business portrays competent brand personality. Competent had the highest (5) coding references. The rest of the brand personality dimensions had 3 coding references each.

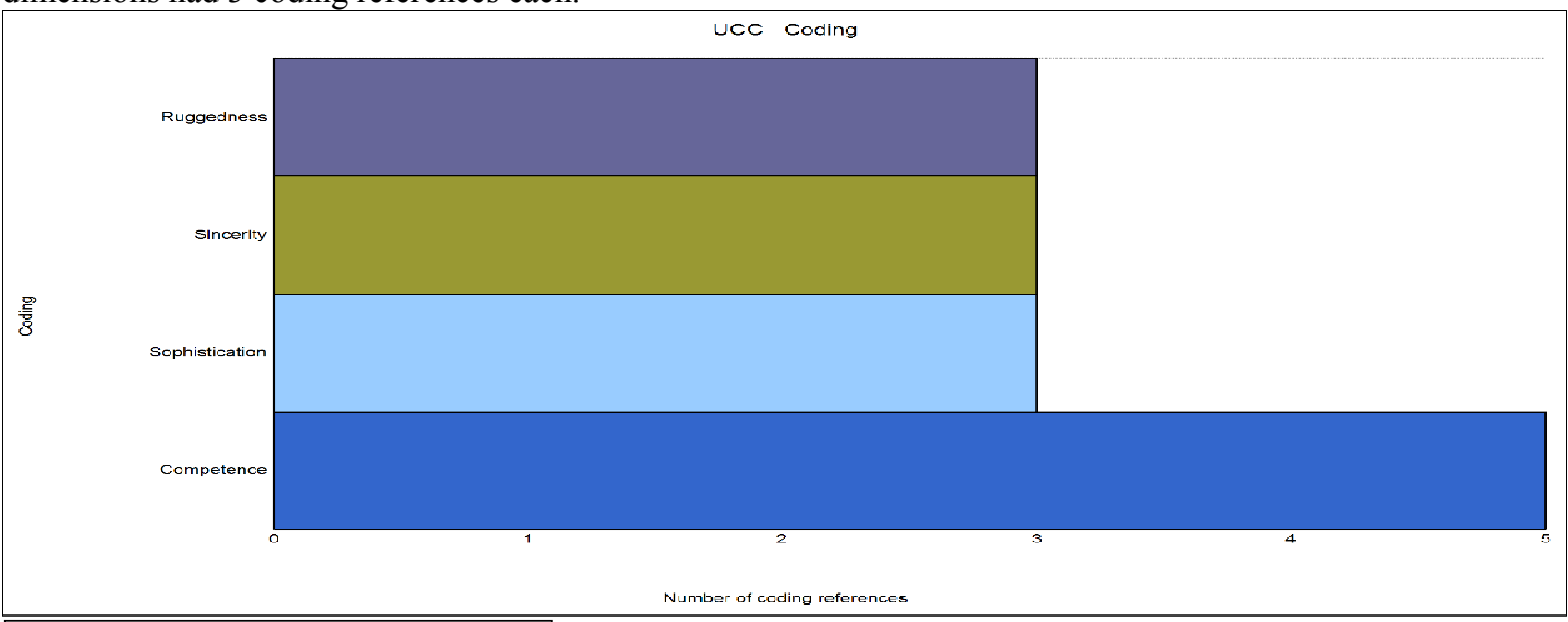

Figure 5:Coding reference: UCC

From table 4 it can be observed that UCC School of Business' portray their competence in professionalism, being industrial, creativity, industrial, enterprises, etc.

\begin{tabular}{|l|l|l|l|l|}
\hline Personality dimensions & Attributes & Frequency & Weighted Percentage (\%) & Similar Words \\
\hline \multirow{5}{*}{ Competence } & professional & 3 & 1.36 & professional \\
\cline { 2 - 5 } & competent & 1 & 0.45 & competent \\
\cline { 2 - 5 } & comprehensive & 1 & 0.45 & comprehensive \\
\cline { 2 - 5 } & creative & 1 & 0.45 & creative \\
\cline { 2 - 5 } & industry & 1 & 0.45 & industry \\
\cline { 2 - 5 } & qualifying & 1 & 0.45 & qualifying \\
\cline { 2 - 5 } & quality & 1 & 0.45 & quality \\
\cline { 2 - 5 } & enterprises & 1 & 0.45 & enterprises \\
\hline \multirow{5}{*}{ Ruggedness } & history & 2 & 0.90 & history \\
\cline { 2 - 5 } & historic & 1 & 0.45 & historic \\
\hline \multirow{5}{*}{ Sophistication } & allied & 1 & 0.45 & allied \\
\cline { 2 - 5 } & equal & 1 & 0.45 & equal \\
\cline { 2 - 5 } & outreach & 1 & 0.45 & outreach \\
\hline & international & 2 & 0.90 & international, national \\
\cline { 2 - 5 } & leading & 2 & 0.68 & leading, result \\
\cline { 2 - 5 } & excellence & 1 & 0.45 & excellence \\
\cline { 2 - 5 } & opportunity & 1 & 0.45 & opportunity \\
\hline
\end{tabular}

Figure 4: UCC's personality attributes 
Comparing the universities in terms of the brand personalities they portray, it was evident that UGBS and KNUST portray similar personality traits as shown in figure 6.

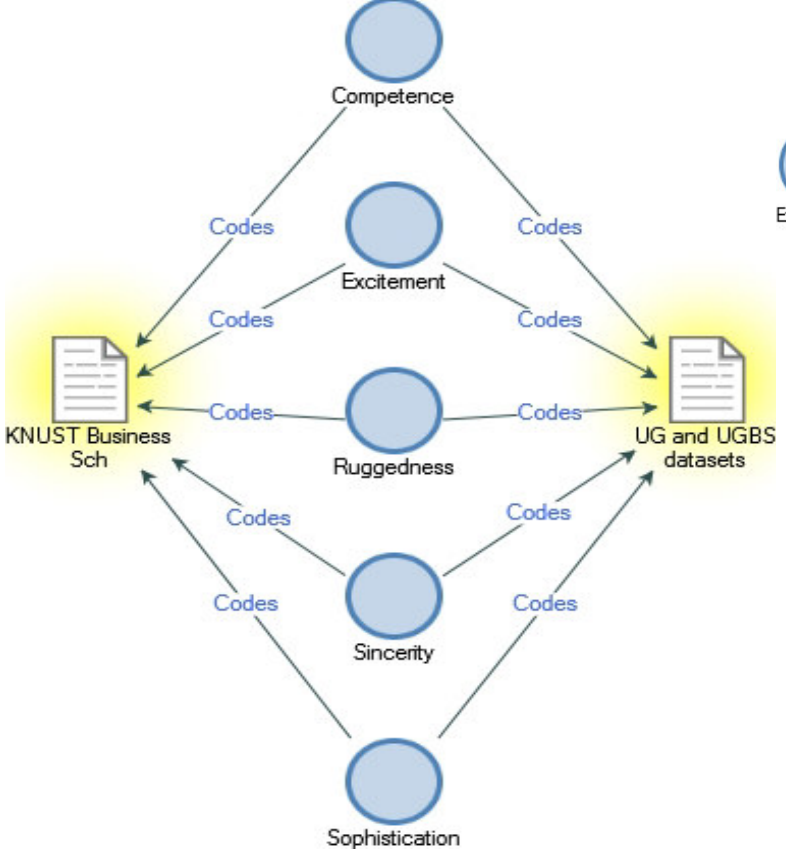

Figure 6: coding comparison: KNUST vs UGBS

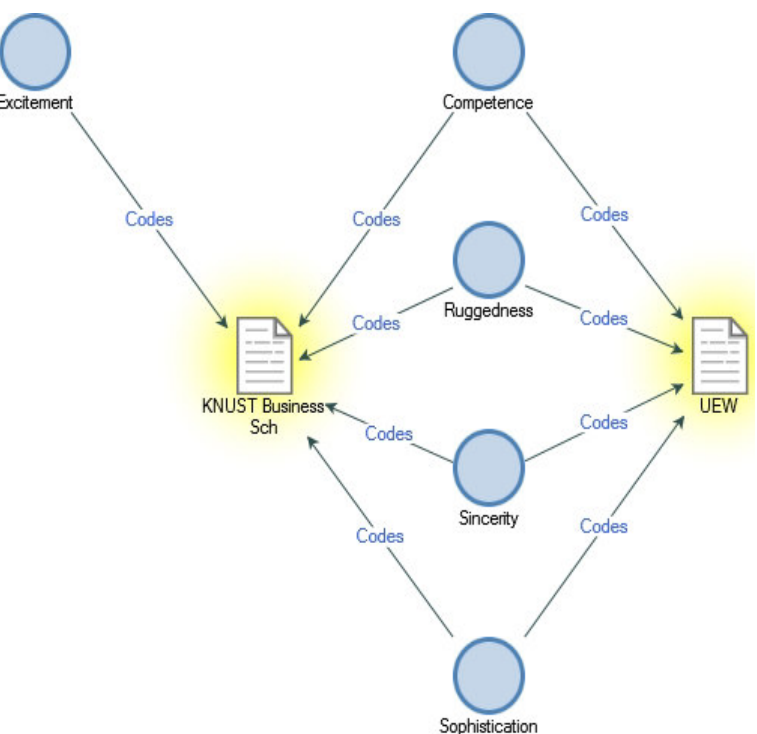

Figure 7: coding comparison: KNUST vs UEW

However, in comparing KNUST Business School and UEW Faculty of Business, it was noted that they all had four (4) out of the five (5) brand personality dimensions in common. The only difference is that KNUST Business School portrayed "Excitement" personality whilst UEW did not (see figure 7). Additionally, a similar trend was noticed between KNUST Business School and UCC School Business. This can be observed in figure 8 .

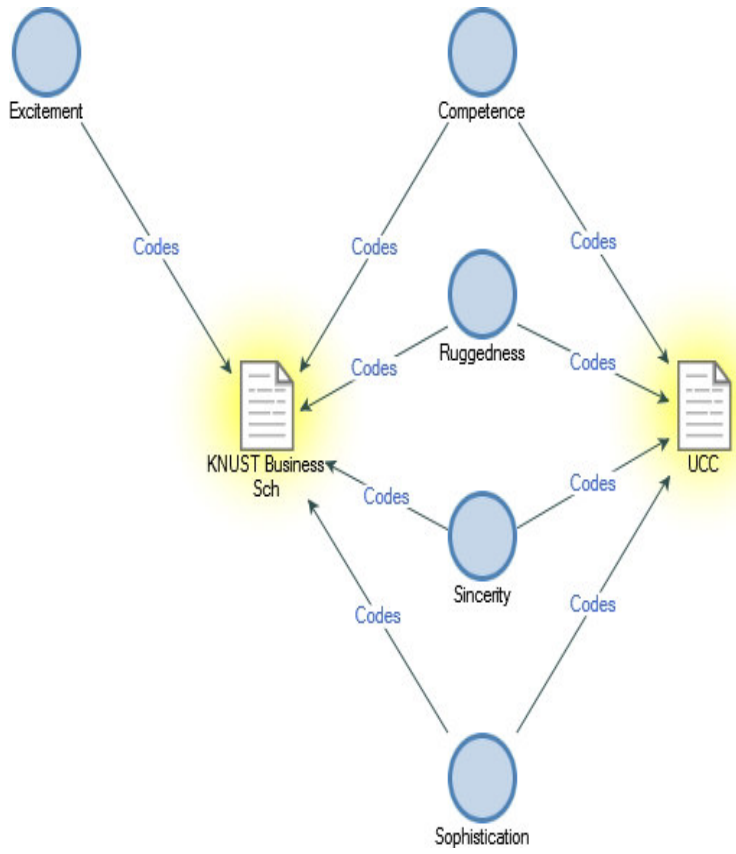

Figure 8: coding comparison: KNUST vs UCC

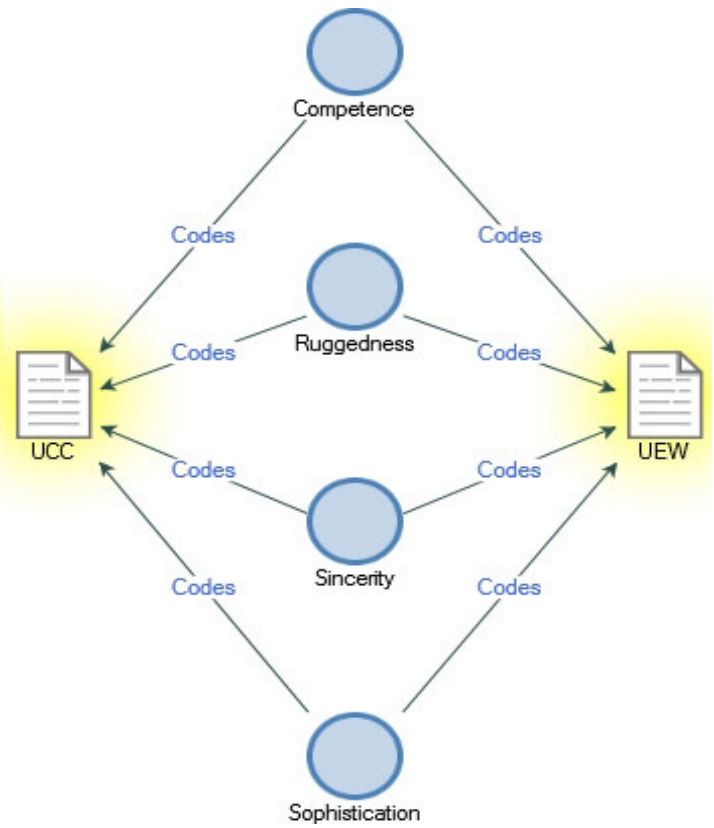

Figure 9: coding comparison: KNUST vs UEW

Meanwhile between UCC School of Business and UEW Faculty of Business, they exhibited similar brand personality as shown in figure 9. However, comparing UCC Business with UGBS, it was observed that UGBS portrayed an "Excitement" personality trait whilst UCC School does not (see figure 10). This was also the case for UGBS and UEW School of Business. The difference was that UGBS exhibited Excitement personality whilst 


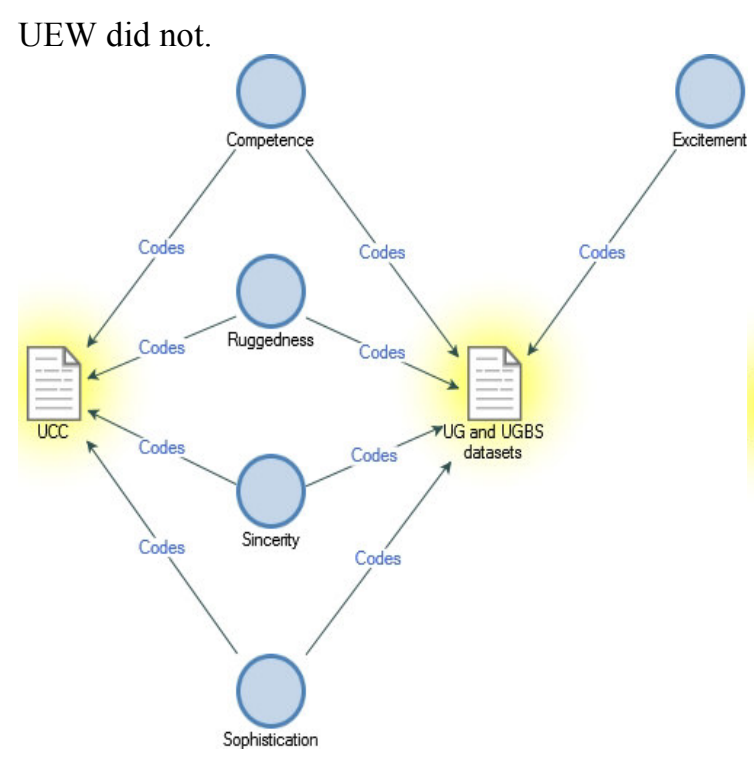

Figure 10: coding comparison: UCC vs UGBS

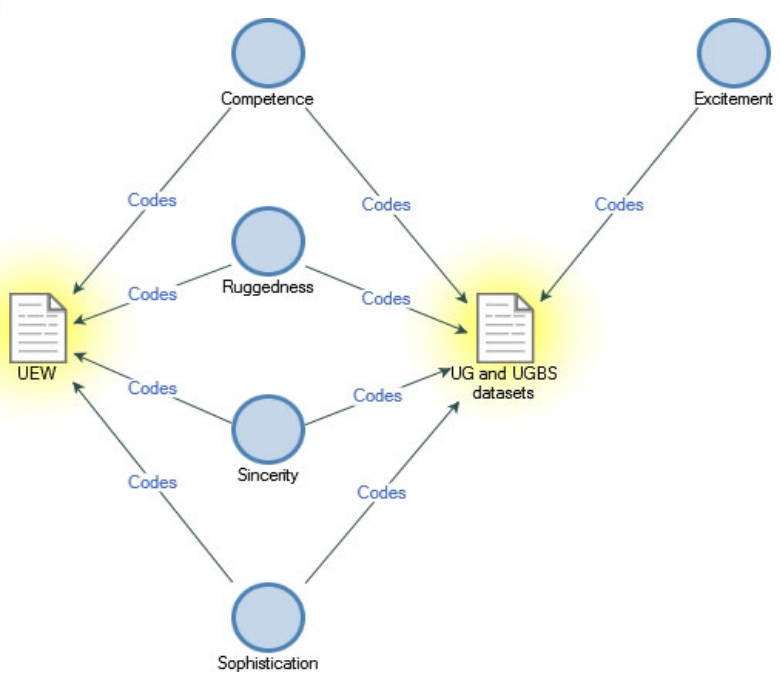

Figure 11: coding comparison: UGBS vs UEW

\subsection{Discussion and Conclusions}

The study has shown that all the four (4) universities have branding strategies in their marketing communications. The findings are consistent with Rutter et al (2016) who established that, most universities used prospectus as the marketing communication and recruitment strategic tool. From the analysis, it can be concluded that 4 Universities understand brand personality and strategically communicate the brand personality they want prospective students and stakeholders to associate with. The study is also consistent with Opoku (2005) who concluded that Business Schools in South Africa portray the five-dimensional brand personality traits on their website. However, the study found additional descriptors that the universities use to portray these brand personalities. These descriptors are captured in tables 1 to 4 . From the analysis and results, it can be concluded that the universities want their publics or students to perceive them as having teaching and research competence. However, a critical analysis of the KNUST Business website showed that they are very strategic in their marketing communications. They communicated many attributes which the other universities did not. Thus, KNUST Business School communicate their brand personality better than the others. The findings also show that, websites are strategic media for brand communication.

\section{REFERENCES}

Aaker, D. A. (1996). Managing brand equity. New York. NY: The Free Press

Aaker, J. (1997). Dimensions of brand personality. Journal of Marketing Research, 34, 347-356.

Aaker, D. A., \& Joachimsthaler, E. (2000). The brand relationship spectrum: The key to the brand architecture challenge. California management review, 42(4), 8-23.

Ailawadi, K. L. \& Keller, K, L. (2004). Understanding retail branding. Conceptual insights and research priorities. Journal of Retailing, 80(4), 331-342

Austin, J. R., Siguaw, J. A., \& Mattila, A. S. (2003). A re-examination of the generalizability of the Aaker brand personality measurement framework. Journal of Strategic Marketing, 11(2), 77-92.

Batra, R., Lehmann, D.R. and Singh, D. (1993), "The brand personality component of brand goodwill: some antecedents and consequences", in Aaker, D.A. and Biel, A.L. (Eds), Brand Equity and Advertising: Advertising's Role in Building Strong Brands, Lawrence Erlbaum Associates, London, pp. 83-96.

Biel, A. (1993). Converting Image into Equity, Papers Presented in Brand Equity and advertising. Hillsdale, NJ, Lawrence Erlbaum Associates

Blackston, M. (1993). Beyond brand personality: building brand relationships. Brand equity and advertising: Advertising's role in building strong brands, 113-124.

Boateng, H., Okoe, A. F., \& Hinson, R. E. (2018). Dark tourism: Exploring tourist's experience at the Cape Coast Castle, Ghana. Tourism Management Perspectives, 27, 104-110.

Boateng, H., \& Abdul-Hamid, I. K. (2017). An evaluation of corporate social responsibility communication on the websites of telecommunication companies operating in Ghana: Impression management perspectives. Journal of Information, Communication and Ethics in Society, 15(01), 17-31.

Boateng, H. \& Narayan, B. (2017). Social capital and knowledge transmission in the traditional Kente textile 
industry of Ghana In Proceedings of RAILS - Research Applications, Information and Library Studies, 2016, School of Information Management, Victoria University of Wellington, New Zealand, 6-8 December, 2016. Information Research, 22(4), paper rails1620.

Doyle, P. (1990), "Building successful brands: the strategic options", Journal of Consumer Marketing, 7 ( 2), 5 20.

Dyson, P., Farr, A., \& Hollis, N. S. (1996). Understanding, measuring, and using brand equity. Journal of Advertising Research, 36(6), 9-22

Fournier, S. (1998). Consumers and their brands: developing relationship theory in consumer research. Journal of Consumer Research, 24, 343-373.

Govers, P. C., \& Schoormans, J. P. (2005). Product personality and its influence on consumer preference. Journal of Consumer Marketing, 22(4), 189-197.

Halliday, J. (1996). Chrysler brings out brand personalities with'97 ads. Advertising Age, 67(40), 3-4.

Kumar, R., Luthra, A. and Datta, G. (2006), "Linkages between brand personality and brand loyalty: a qualitative study in an emerging market in the Indian context", South Asian Journal of Management, 13 (2), $11-35$.

Neuman, W. (1997). Social research methods: qualitative and quantitative approaches. Needham Heights, MA: Allyn \& Bacon.

Opoku, R., Abratt, R., \& Pitt, L. (2006). Communicating brand personality: are the websites doing the talking for the top South African business schools?. Journal of Brand Management, 14(1-2), 20-39.

Plummer, J. T. (1985). How personality makes a difference. Journal of Advertising Research, 24(6), $27-31$.

Slaughter, J. E., Zickar, M. J., Highhouse, S., \& Mohr, D. C. (2004). Personality trait inferences about organizations: development of a measure and assessment of construct validity. Journal of Applied Psychology, 89(1), 85.

Weber, R. P. (1990). Basic content analysis. Beverly Hills, CA: Sage

\section{PROFILE OF AUTHORS}

**Mrs. Rhodalene Amartey is a seasoned lecturer and a researcher with an insatiable desire for knowledge and ready to impart to others. She holds a Bachelor's degree in Sociology and a Masters' degree in Business Administration (Marketing Option) respectively from the University of Ghana. She also holds a professional marketing qualification from the Chartered Institute of Marketing, UK. Currently, she is a final year Doctoral student $(\mathrm{PhD})$ in Business Administration at the Accra Institute of Technology, a private university affiliated with the Open University in Malaysia

** Prof. Nathan Kobina Austin joined UPSA in 2018 as a full professor in the Faculty of Management and Dean of Doctoral Programmes. He has thirty (30) years of teaching, academic programmes administration and services industry experience. Besides adjunct positions at Ghana Institute of Management and Public Administration and Kwame Nkrumah University of Science and Technology, Ghana, he has held full-time positions teaching, supervising graduate student research and managing academic programmes and departments in universities in Malaysia, Australia and the United States of America. Prior to joining academia, he served in a number of sales and marketing management positions in the hotel, brewery and tourism industries in Ghana. Prof. Austin holds a $\mathrm{PhD}$ in Tourism -from Strathclyde University, Glasgow, UK - 1998, a PGrad Certificate in Doctoral Research Methodology from Strathclyde University, Glasgow, UK - 1996, MSc in Tourism Marketing - Surrey University, Guilford, UK - 1988 and Dip in Marketing - Chartered Institute of Marketing, UK - 1984. As a seasoned researcher, he has published over 30 articles 